\title{
Performance and Emission Analysis of Diesel Engine using palm seed oil and diesel blend
}

\author{
Maulik A Modi1, Tushar M Patel2, Gaurav P Rathod3 \\ ${ }^{I}$ (ME Scholar, Department of Mechanical Engineering , LDRP-ITR/ KSV University,India) \\ ${ }_{2}^{2}$ (Associate Professor, Department of Mechanical Engineering , LDRP-ITR/ KSV University,India) \\ ${ }_{3}^{3}$ (Assistant Professor, Department of Mechanical Engineering , LDRP-ITR/KSV University,India)
}

\begin{abstract}
The Fossil fuels play an important role in the world energy market. The World Energy Outlook claims that energy generated from fossil fuels will remain the major source. Population of the world increases day by day and living standard of the people will improve, there will be a shortage of source of energy. So researchers are continuously trying to find out the best alternative fuel. As an alternative fuel, Bio fuel required for becoming the fuel source for the future. With the use of Bio fuel there is no more modification is required in Existing engine. This study shows the comparison of performance and emission characteristics of diesel engine using diesel and biodiesel as palm seed oil with various proportions by volume (B10, B20, and B30). And in this research paper we briefly discuss replacement of fossil fuel with palm seed oil and diesel and its effect on the engine performance and emission characteristics.
\end{abstract}

Keywords: Diesel Engine, Palm seed oil, Exhaust Gas Analyzer.

\section{Introduction}

In India diesel engines are widely used for transport and agricultural machinery due to its superior fuel efficiency. The increasing cost of petrol has made people to depend largely on diesel based engines. Due to depletion and higher cost of petroleum based fuels researchers around the world look for alternate fuel and trying to find out the best alternative fuel, which is used as a biodiesel, M.A. Kalam et.al shows in his research paper that Waste cooking oils such as, C5 and P5 reduce brake power by $0.7 \%$ and $1.2 \%$ respectively compared with $\mathrm{B} 0 . \mathrm{C} 5$ and $\mathrm{P} 5$ reduce $\mathrm{CO}$ by $7.3 \%$ and $21 \%$ respectively compared with $\mathrm{B} 0 . \mathrm{C} 5$ and $\mathrm{P} 5$ reduce $\mathrm{HC}$ by $23 \%$ and $17 \%$ respectively compared with B0. C5 reduces by $1 \%$ and the P5 increases by $2 \%$ NOx emission compared with B0. [1] H. Sharon et.al shows in his research paper that B25 \& B50 showed better performance. [2] I.M. Rizwanul Fattah et.al shows in his research paper that the addition of antioxidants increased power output due to the combined effect of higher mass flow. B100 and B20 produced about $14.9 \%$ and $4.71 \%$ higher BSFC, respectively, compared to B0. B20 produced a mean increase in NOx emission of $16.9 \%$ compared to B0. The addition of antioxidants produced mean reductions in NOx emissions of $12.6 \%$ and $9.8 \%$ relative to B20. [3] R.Prakash et.al shows in his research paper that the waste plastic oil emulsions exhibits longer ignition delay than diesel fuel. increase in the brake thermal efficiency was 6.34, 9.5 and 9.3 for WPO diesel emulsion, which is higher than diesel fuel operation the exhaust gas temperatures of different WPO diesel emulsions are lower than diesel fuel operation and reduction in NOx emissions was 19.21, 28.38 and 34.81 for WPO diesel emulsion. The $\mathrm{CO}$ emissions of WPO-diesel emulsions are slightly higher than diesel fuel due to reduction in gas temperature the hydrocarbon emissions increases by $14.28 \%$ and $7.14 \%$. [4] K. Sivaramakrishnan \& P. Ravikumar found that a diesel engine operating at a high compression ratio - 17.9, high pressure 230 bar, Injection timing of $27^{\circ} \mathrm{bTDC}$, Biodiesel -diesel blend B30. And Brake power-3.64 Kw achieves the optimum engine performance. The results are well supported by the findings of our confirmatory test. [5] Hindren A. Saber et. al shows in research paper At higher engine speeds (above 2500 r.p.m) the brake specific fuel consumption increases because of high friction lose. Brake thermal efficiency increases with increasing brake mean effective pressure. The heating of air affected combustion, because of enlargement of air size at heating with same amount of fuel, leads to less air available to burn with fuel led to high fuel consumption.[6] Nilamkumar S Patel et. al concluded that D70 S30 found best optimum blend compare to the other blend. This blend can directly used in the single cylinder 4-stroke diesel engine without modification of the engine. It is also concluded that as the sesame oil concentration increased in the diesel the fuel consumption increased.[7]

\section{Palm Seed Oil}

The fuel properties like flash point, fire point, kinematic viscosity, density, calorific value. These fuel properties were compared with diesel fuel. Flash point and fire point were higher than diesel this confirmed the safety of biodiesel storage. Kinematic viscosity and density were higher than diesel this may result in improper spray characteristics. Cetane number was higher than diesel and it would have positive impact on combustion quality of biodiesel. 
Table-1.The fuel Properties of Palm seed oil and Diesel

\begin{tabular}{|c|c|c|c|c|}
\hline Fuel Property & ASTM & Palm Seed Oil & Diesel & Unit \\
\hline Density at $15^{\circ} \mathrm{C}$ & D4052 & 882 & 830 & $\mathrm{Kg} / \mathrm{m}^{3}$ \\
\hline $\begin{array}{c}\text { Kinematic Viscosity at } \\
40^{\circ} \mathrm{C}\end{array}$ & D445 & 7.01 & 3.05 & $\mathrm{cSt}$ \\
\hline Flash Point (PMCC) & D93 & 110 & 56 & ${ }^{\circ} \mathrm{C}$ \\
\hline Fire Point & D93 & 140 & 63 & ${ }^{\circ} \mathrm{C}$ \\
\hline Cetane Number & D613 & 77 & 51 & ---- \\
\hline Sulphated Ash & D874 & NIL & 0.001 & $\%$ by mass \\
\hline Gross Calorific Value & D4809 & 33360 & 42000 & $\mathrm{Kj} / \mathrm{kg}$ \\
\hline
\end{tabular}

III. Experimental Set Up

Experiments were conducted with Diesel and different volume proportions of palm seed oil as a Blend by $10 \%, 20 \%$ and $30 \%$ with Diesel. And take reading for different load condition. And do comparison between Diesel, B10, B20 and B30 blend.

In this experiment, diesel engine is used and connected with the eddy current dynamometer with the help of dynamometer, varies the load on the engine or load remain constant .Gas analyzer is used to find the emission characteristic of exhaust gas. The reading takes by constant load or by varying the load on the engine using the dynamometer. Engine performance such as brake power, indicated power, brake thermal efficiency, brake specific fuel consumption etc. found from the experiments. First only diesel fuel is used and emission characteristics and engine performance is found .Then the blending of diesel and Palm seed oil at different proportion like $10 \%, 20 \%$, and $30 \%$ concentration is used to find the emission characteristics and engine performance of the engine. By taking the analysis of the various blend of diesel and palm seed oil to get the optimum value of blend for better quality of emission and performance characteristics of Diesel Engine.

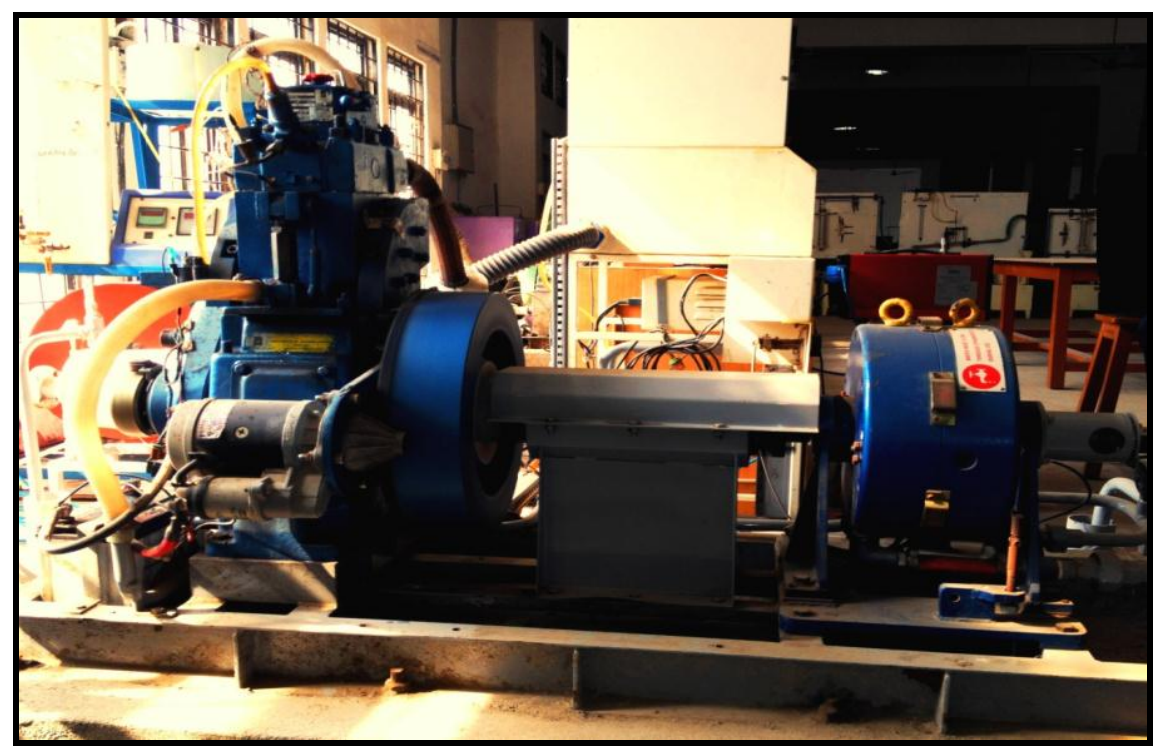

Fig. 1 Engine Testing Kit

Table-2.Technical Specification

\begin{tabular}{|l|l|}
\hline Model & TV1 \\
\hline Make & Kirlosker Oil Engines \\
\hline Type & Four stroke, Water cooled, Diesel \\
\hline No. Of Cylinder & One \\
\hline Bore & $87.5 \mathrm{~mm}$ \\
\hline Stroke & $110 \mathrm{~mm}$ \\
\hline Combustion Principle & Compression ignition \\
\hline Cubic Capacity & 0.661 liters \\
\hline Compression Ratio & $17.5: 1$ \\
\hline
\end{tabular}




\section{Engine Performance.}

\section{Result And Discussion}

(1) Brake Thermal Efficiency:- Fig.2 shows the variation of a brake thermal efficiency for test fuel at different load condition. From fig.-2 it is clearly shows that BTE For diesel fuel increased continuously for no load to full load condition. And for $10 \%$ of blend BTE increased upto $30 \%$ lower than diesel fuel. And into 20 \& $30 \%$ of blend BTE increased upto $37 \& 41 \%$ respectively. The thermal efficiency of the engine is improved by increasing the concentration of the biodiesel in the blends.

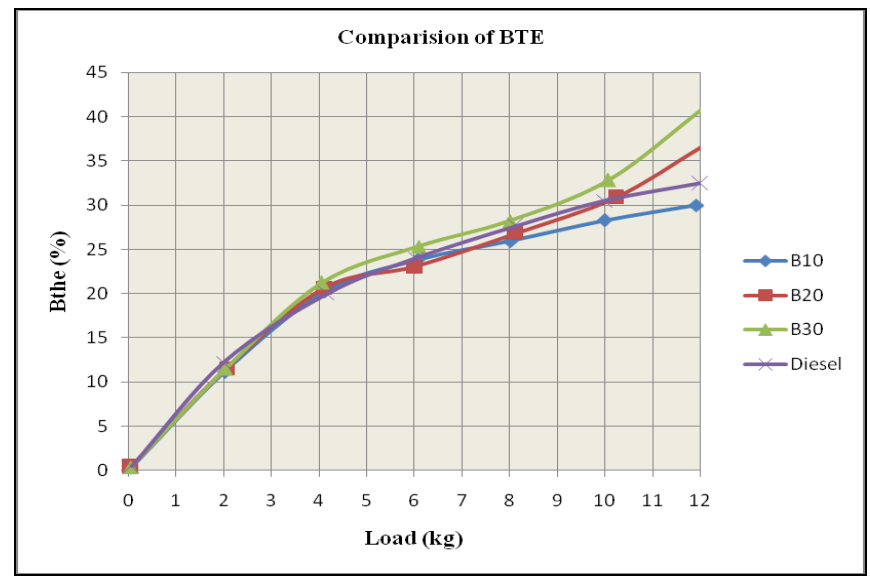

Fig. 2 Variation of Brake Thermal Efficiency for Test Fuel at different Load

(2) Specific Fuel Consumption:- Fig.3 shows the variation of a specific fuel consumption for test fuel at different load condition. From figure it is clearly shows that SFC. For diesel fuel reduced continuously for no load to full load condition. And for $10 \%$ of blend SFC reduced same as diesel fuel. And into $20 \& 30 \%$ of blend SFC reduced upto $0.24 \& 0.18 \mathrm{~kg} / \mathrm{kwh}$ respectively. The thermal efficiency of the engine is improved by increasing the concentration of the biodiesel in the blends.

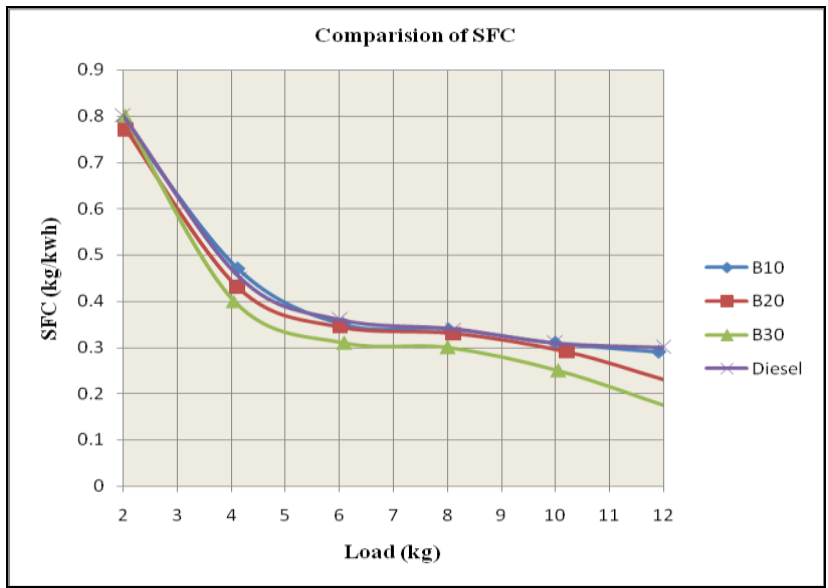

Fig. 3 Variation of Specific Fuel Consumption for Test Fuel at different Load

(3) Indicated Power:- Fig.4 shows the variation of indicated power for test fuel at different load condition. From figure it is clearly shows that IP For diesel fuel increased continuously for no load to full load condition. And for $10 \%$ of blend IP increased higher than diesel fuel. And into $20 \& 30 \%$ of blend IP increased upto $5.55 \& 5.52 \mathrm{kw}$ respectively. The Indicated Power of the engine is improved by complete combustion of $10 \%$ blend due to better atomisation compare to other blend. 


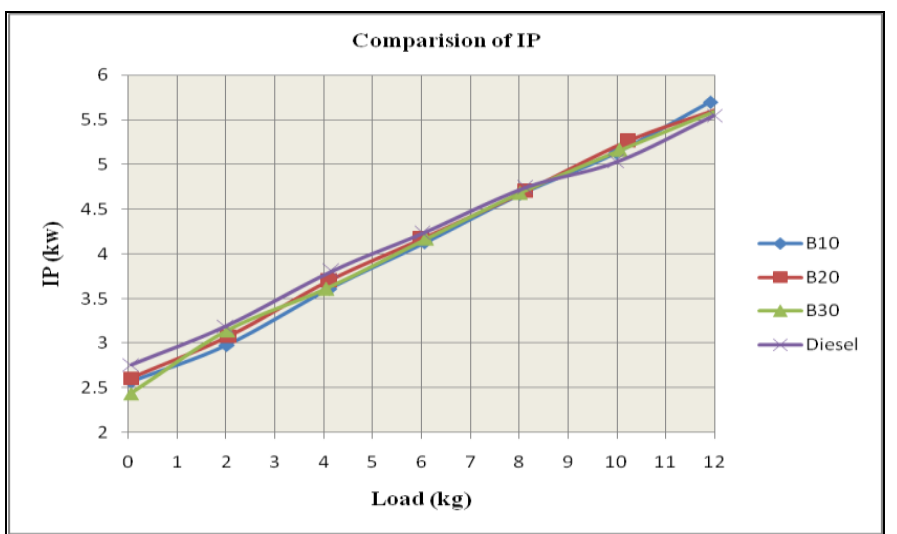

Fig. 4 Variation of Indicated Power for Test Fuel at different Load

\section{EXHAUST EMISSION}

(1) NOx (Nitrogen Oxide):- Fig.5 shows the variation of NOx for test fuel at different load condition. From fig.-5 it is clearly shows that NOx for diesel fuel increased continuously for no load to full load condition. And for $10 \%$ of blend NOx reduced up to $6359 \mathrm{ppm}$ lower than diesel fuel. And into $20 \& 30 \%$ of blend NOx reduced up to $6483 \& 6200 \mathrm{ppm}$ respectively. The NOx of the engine is reduced by means of incomplete combustion of fuel

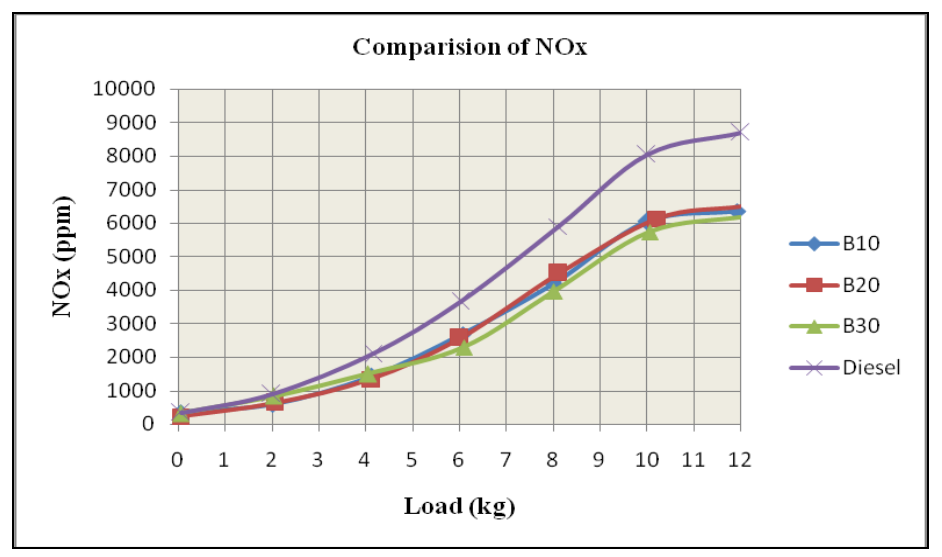

Fig. 5 Variation of NOx for Test Fuel at different Load

(2) CO (Carbon Monoxide):- Fig.6 shows the variation of a Carbon Monoxide for test fuel at different load condition. From fig- 6 it is clearly shows that $\mathrm{CO}$ by \%volume For diesel fuel reduced continuously for no load to full load condition. And for $10 \%$ of blend CO by \%volume reduced lower than diesel fuel. And into 20 $\& 30 \%$ of blend CO reduced up to $0.040 \& 0.037 \%$ by volume of total exhaust gas respectively.

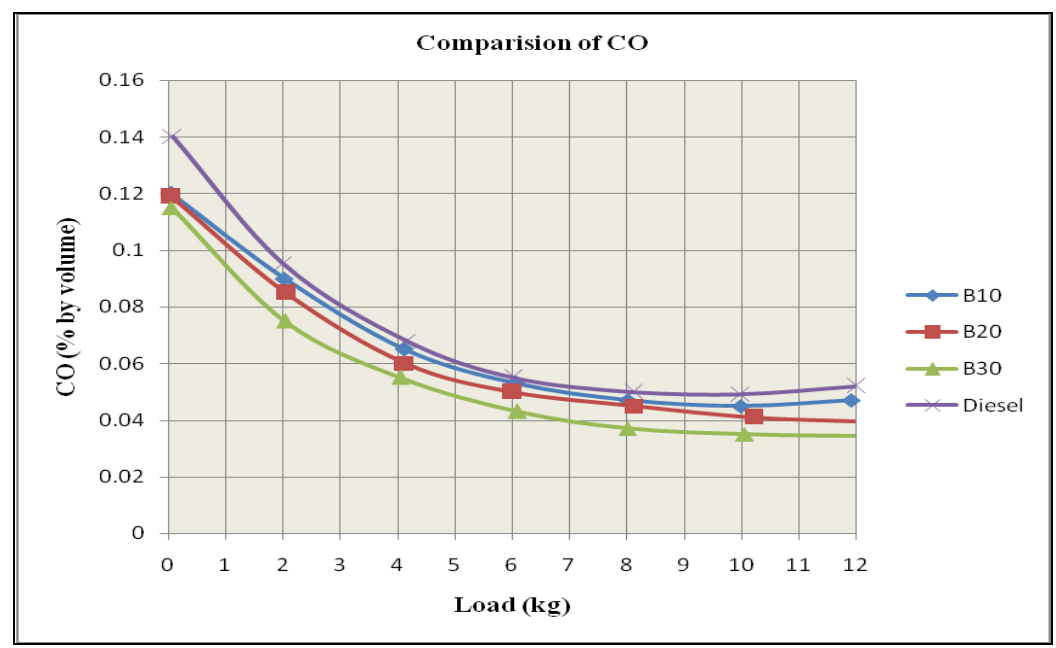

Fig. 6 Variation of Carbon Monoxide (CO) for Test Fuel at different Load 
(3) $\mathrm{CO}_{2}$ (Carbon Dioxide):- Fig.7 shows the variation of a Carbon Dioxide for test fuel at different load condition. From fig-7 it is clearly shows that $\mathrm{CO}_{2}$ by \%volume for diesel fuel increased continuously for no load to full load condition. And for $10 \%$ of blend $\mathrm{CO}_{2}$ by $\%$ volume increased but lower than diesel fuel. And into 20 $\& 30 \%$ of blend $\mathrm{CO}_{2}$ increased up to $2.5 \& 2.4 \%$ by volume of total exhaust gas respectively.

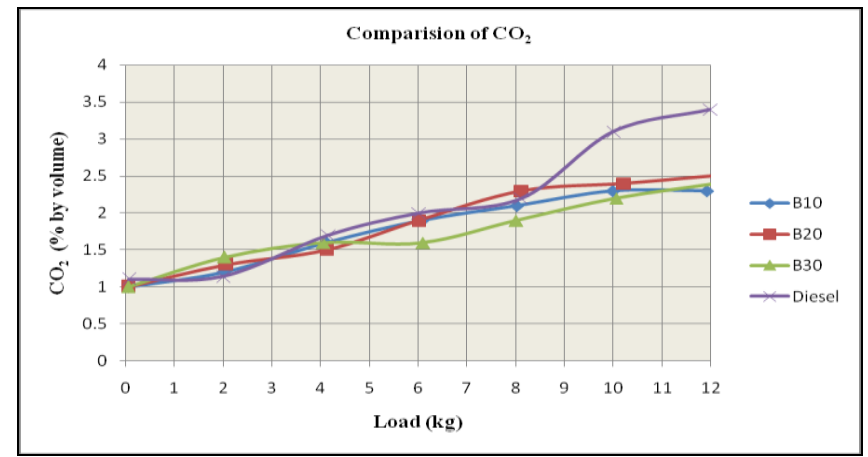

Fig. 7 Variation of Carbon Dioxide $\left(\mathrm{CO}_{2}\right)$ for Test Fuel at different Load

(4)HC (Hydro Carbon):- Fig.8 shows the variation of Hydro Carbon for test fuel at different load condition. Fig-8 clearly shows that HC for diesel fuel increased continuously for no load to full load condition. And for $10 \& 20 \%$ of Blend HC increased but lower than diesel. And for $30 \%$ of blend HC increased no load to $8 \mathrm{~kg}$ load and after that for full load condition HC decreased.

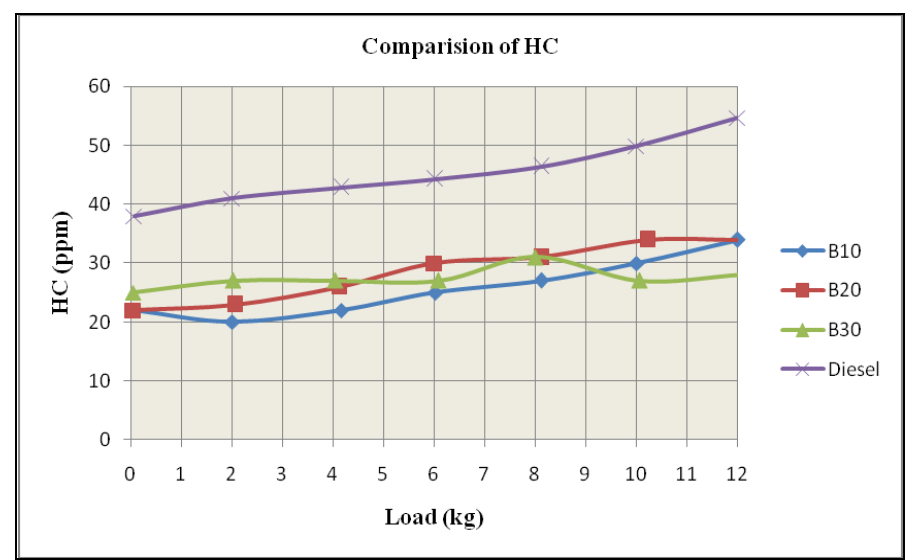

Fig. 8 Variation of Hydro Carbon (HC) for Test Fuel at different Load

\section{Conclusion}

From the analysis, it concluded that $30 \%$ blend of palm seed oil found best blend compare to the other blend. This blend can directly used in the single cylinder 4-stroke diesel engine without modification of the engine. For B30 blend NOx reduced compare to other blend.

\section{References}

[1] M.A. Kalam, H.H. Masjuki, M.H. Jayed, A.M. Liaquat, "Optimizing Emission and performance characteristics of an indirect ignition diesel engine fuelled with waste cooking oil'" journal homepage: www.elsevier.com/locate/energy, Energy 36 (2011) $397-$ 402.

[2] H. Sharon, K. Karuppasamy, D.R. Soban Kumar, "A test on DI diesel engine fueled with methyl esters of used palm oil" journal homepage: www.elsevier.com/locate/energy, Renewable Energy 47 (2012) 160-166.

[3] I.M. Rizwanul Fattah , H.H. Masjuki, M.A. Kalam, M. Mofijur, M.J. Abedin, "Effect of antioxidant on the performance and emission characteristics of a diesel engine fueled with palm biodiesel blends', journal homepage: www.elsevier.com/locate/energy, Energy Conversion and Management 79 (2014) 265-272.

[4] R.Prakash, R. K.Singh, and S.Murugan, "Experimental Studies on a Diesel Engine Fueled with Wood Pyrolysis Oil Diesel Emulsions", International Journl of Chemical Engineering and Applications, Dec2011, Vol. 2, No. 6

[5] K. Sivaramakrishnan \& P. Ravikumar, "Performance optimization of karanja biodiesel engine using taguchi approach and multiple regressions"' ARPN Journal of Engineering and Applied Sciences, April2012, Vol.7.No.4,PP. 506-516.

[6] Hindren A. Saber, Ramzi R. Ibraheem Al-Barwari, Ziyad J. Talabany, "Effect of ambient air temperature on specific fuel consumption of naturally aspirated diesel engine Journal of Science and Engineering', March2013, Vol. 1, PP. 1-7.

[7] Mr.Nilamkumar S Patel, Prof. Tushar M Patel [June2012]- "Performance characterization of single cylinder diesel engine fuelled with Sesame oil - diesel and its blend with Ethanol', International Journal of Engineering Research \& Technology, Vol. 1, PP. 1-4. 